\title{
Morphological non-blocking in Dutch plural allomorphy - a contrastive approach
}

\begin{abstract}
Dutch simplex nouns ending in schwa have two regular plural forms, e.g. bode-s/bode-n 'messengers'. This means that neither of the two allomorphs $-s$ and $-n$ is blocked. Such regular non-blocking is non-existent in the closely related languages German and Afrikaans. To identify the reasons for this divergence, the history of plural marking in the three languages is compared. Based on the historical observations it is argued that the doublets in Dutch are retained due to the output principle of plurals ending in a trochaic foot, according to which both $-s$ and $-n$ may apply without preference on stems with non-final stress. ${ }^{1}$
\end{abstract}

\section{Introduction}

Most Dutch nouns are characterized by a non-variable and highly predictable plural allomorph. The two productive suppletive plural allomorphs of Dutch, ${ }^{2}-s$ and $-(e) n$, are conditioned according to a rhythmic rule stating that the plural form of a noun must end in a trochaic foot: The allomorphs $-s$ and - more seldom $--n$ therefore appear regularly with bisyllabic stems ending in a trochee, whereas -en is found with monosyllabic stems, cf. (1).

$$
\text { helper-s 'helpers', sluitel-s 'keys', stoel-en 'chairs', huiz-en 'houses' }
$$

Nevertheless, Dutch plural formation is often described as highly variable and unpredictable. VAN HAERINGEN (1956), e.g., describes the Dutch plural system as "unsystematic, in a way artistically unsystematic" (p. 36) in contrast with the systems of German and English. The reason for this description is that a limited number of nouns behave unsystematically by building their plural forms in violation of

1 I would like to thank Antje Dammel, Therese Leinonen, Martin Neef, and two anonymous reviewers for valuable comments on an earlier version of this paper, and Janet Duke for proof-reading the manuscript. Of course, all remaining mistakes are mine.

2 For the description of allomorphy, I follow HASPELMATH (2002:26-30) in distinguishing between phonological and suppletive allomorphs. In Dutch, the (e) $n$-suffix constitutes the two formally similar phonological allomorphs $-e n$ and $-n$, the distribution of which is totally predictable from the final sound either ending in schwa or not. The allomorphs $-s$ and -(e)n, instead, are related only on the level of their function as plural allomorphs. From a formal point of view, they are not at all similar, but rather suppletive. The allomorphs $-s$ and $-(e) n$ are therefore related as 'suppletive allomorphs', while the formal variants $-e n$ and $-n$ are related as 'phonological allomorphs'.

3 My translation from Dutch "onsystematisch, in zeker opzicht artistiek onsystematisch". 
the prosodic rule, as in (2a), or taking both of the plural allomorphs without a clear preference, see $(2 b){ }^{4}$

(2) a engel-en 'angels', christen-en 'Christians', kok-s 'cooks', oom-s 'uncles', reünie-s 'reunions', kind-eren 'children'

b appel-s/appel-en 'apples', handelaar-s/handelar-en 'merchants', directeur-s/directeur-en 'headmasters', groente-s/groente-n 'vegetables'

The examples in (2b) contradict the basic theoretical assumption of blocking in morphology. In simple terms, blocking is "the nonoccurrence of one form due to the simple existence of another" (ARONOFF 1976:43) and historically results in the resolution of functional doublets. In rule-based accounts, that means that an irregular form can block the application of a regular rule. A simple example: The existence of the irregular English plural form children hinders the existence of an equivalent regular form with $s$-plural, accordingly *childs.

KIPARSKY (2005) approaches blocking as a relation between competing expressions. In his account, potential output expressions for the same input meaning are evaluated with respect to the two constraints of ECONOMY and EXPRESSIVENESS. The usual cases for blocking are encountered when either one of the outputs is more complex than the other (according to ECONOMY) or expresses the input meaning more completely than the other (according to EXPRESSIVENESS).

Interestingly, Kiparsky does not view blocking as obligatory. Instead, when both expressions are equally economical and expressive, free variation may occur. In Kiparsky's view this is the only situation not necessarily resulting in blocking, with the further restriction that no additional constraints may block one of the variants. ${ }^{5}$

In some parts of the Dutch noun system, doublets exist and even remain stable to a large extent. In this article the question of morphological blocking will therefore be addressed by focusing on a phenomenon of non-blocking. ${ }^{6}$ We will show that non-blocking based on free variation may occur when plural formation is dominantly restricted by prosodic conditions on the output - as is the case in Dutch, in which plural formation is based on ending in a trochaic foot. We will argue that no further preference for a single allomorph is found when a plural form follows this general principle, the allomorphs in question are equally expressive and economical according to Kiparsky's account, and no further constraints apply.

4 Irregularity through stem alternation is also found in a small number of nouns, cf. stad - steden 'city' and through loaned plural formation, cf. genus - genera 'gender'. To my knowledge there are no quantitative studies listing all of these exceptions. Hence, it is impossible to provide the exact number of words which behave in this way. Counting all the nouns listed in HAESERYN et al. (1997:165-184) as belonging to category (2a), this amounts to 61 nouns (see Appendix 1). Counting the nouns belonging to category $(2 \mathrm{~b})$ at the same place, leaving nouns in schwa aside (see section 2 below), this amounts to 61 nouns (see Appendix 2). Since some derivate groups are not included in the lists with their whole inventory, and Haeseryn et al. provide examples rather than complete overviews, the groups are a bit bigger than these numbers indicate.

5 Because the following deals with a special empirical problem, the theoretical discussion of (morphological) blocking is left at this point and taken up again in section 4. For further discussion see e.g. EMBicK (2007), KROCH (1994), or POSER (1992).

6 For a discussion of other non-blocking cases cf. e.g. FeHRINGER (2004), who deals with variants like -(e)lijk in Dutch word formation, or -(e)s in the German genitive singular. 
The general patterns of plural allomorphy and its conditioning in current Dutch will be explained in section 2. The most interesting cases of doublets will be pointed out in this overview by differentiating between two groups of nouns, one consisting of nouns with irregular plural formation and one regularly characterized by non-blocking. The second of these groups, which will be of main interest in this article, is characterized by the structural property of ending in a schwa. Nouns of this structure usually have no preference for $-n$ or $-s$ in plural formation, cf. schade$s / s c h a d e-n$ 'damages'. In contrast with most blocking accounts, in which it is usual to focus on single words (cf. children vs. ${ }^{*}$ childs) as instances of blocking, we will thus deal with a regular process for the formation of doublets.

In section 3, the origin and development of morphological (non-)blocking will be described from a historical point of view. The history of Dutch will be contrasted with the history of closely related German (section 3.1), which has established morphological blocking in noun morphology to a much greater extent than Dutch. After that, the history of Dutch is also compared to that of Afrikaans, which originated from Dutch dialects in the $17^{\text {th }}$ century (section 3.2). Morphological blocking on nouns was also established to a greater extent in Afrikaans than in Dutch. The main goal of the contrastive study is to determine where the histories of the closely related languages differ, resulting in contrasting developments with regard to morphological blocking.

The goal of this paper is to identify factors which are influential for the establishment or non-establishment of blocking. It will be shown that a specific constellation of factors led to a situation which made morphological blocking unnecessary in the specific case of nouns ending in a schwa in Dutch. Due to this lack of necessity, no blocking principles were established in contrast with most other nouns.

The argument presented in this paper is based on the general theoretical assumption that morphological meaning is not only expressed through morphological segments, but rather through more general output structures, e.g. prosodic principles. For example, in Dutch the prosodic output structure of ending in a trochaic foot is generally associated with plural forms on nouns. ${ }^{7}$ Such output-based accounts have been developed in perception-based morphological theories in recent years, e.g. in some a-morphous accounts (cf. ANDERSON 1992, NEEF 1996). Concepts from schema theory (cf. BYBEE 1988, KöPCKE 1993) are used to support this argument. On the background of these theoretical accounts, it is argued in section 4 that there may be cases in which morphological blocking is unnecessary, because from an output perspective - a grammatical function is equally well expressed by different markers.

7 Of course there are also stems consisting of trochaic feet - i.e. also in their singular form - like appel 'apple'. The assumptions are based on a prototype theory abstracting from the fact that most of the Dutch noun stems are monosyllabic, whereas plural forms are nearly always at least bisyllabic (cf. section 4 for further details). 


\section{Plural allomorphy in current Dutch}

Dutch belongs to those Germanic languages which have reduced complexity in noun morphology to a considerable degree (cf. DAMMEL \& KÜRSCHNER 2008). Case morphology was abolished in Dutch. The number of allomorphs for the number category was also reduced, resulting in only two productive suppletive plural allomorphs (-s and $-(e) n)$, while the singular is always unmarked. ${ }^{8}$

According to BoOIJ (2002:24) these two plural allomorphs are conditioned by a prosodic output condition: "A plural noun ends in a trochee." For this reason, monosyllabic nouns usually build the plural form by adding the syllabic suffix -en, which is most often pronounced as [ə], cf. huiz-en 'houses'. ${ }^{9}$ The same holds for nouns ending in a stressed syllable, cf. kolóss-en 'colossuses', and derivates ending in a syllable which bears secondary stress, cf. verzamel+ing-en 'assemblies', weten+schapp-en 'sciences' etc.

When a stem ends in an unstressed syllable, the unsyllabic suffixes $-s$ or $-n$ are used. In nouns ending in a combination of schwa and a sonorant, only $-s$ appears, cf. lepel-s 'spoons', bezem-s 'brooms'. Nouns ending in a schwa can often have either $-s$ or $-n$, as described in deeper detail below. Words with a variable stress position appear with a syllabic as well as an unsyllabic suffix, depending on the stress position chosen in the stem, cf. mótor-s/motór-en 'motors'. Taking all these conditions into account, the distribution can be most accurately described through the output condition that a plural form must end in a trochaic foot. ${ }^{10}$

Although the plural allomorphs of most nouns are thus conditioned highly reliably, a part of the Dutch noun lexicon is characterized by doublets in plural formation. There are two types of doublets: In the first type, one form agrees with the prosodic conditioning principle, whereas the other form deviates from it. For example, doorn-en 'thorns' and teken-s are in conformity with the trochee principle in contrast with the alternative plural forms doorn-s and teken-en. Examples of this type are listed in Appendix 2. In the second type, both forms are in accordance with the trochee principle. The two unsyllabic suffixes $-s$ and $-n$ compete in one specific context. This is on polysyllabic nouns ending in a schwa, i.e. mostly a trochaic foot, cf. schade-s vs. schade-n 'damages', type-s vs. type-n 'types', vitamine-s vs. vitamine- $n$ 'vitamins' etc. Nouns of this kind are not very frequent in Dutch, in which final schwa on stems was apocoped to a high extent. Still, the remaining nouns are very often characterized by varying plural formation - the only fully regular exception being diminutives in $-j e$ which always take an $s$-suffix, cf.

8 This holds for the central part of the native lexicon. The morphology of foreign nouns does not always conform to these basic properties of the Dutch morphological system.

9 The pronunciation of the en-allomorph is subject to variation in regional standard varieties. In the North-Eastern and South-Western parts of the Dutch-speaking area, final $-n$ is often pronounced, while $n$-apocope shapes most of the other areas, cf. DE SCHUTTER (2001). The $n$-less form is generally considered to be the superregional variant (cf. HAESERYN et al. 1997:167).

10 Cf. also VAN DER Hulst \& KoOIJ (1998). Of course, not all nouns are subject to this distribution, cf. the irregularities in (2a) above, section 1. Furthermore, irregular stem alternation is found on some nouns, cf. schip - schepen, stad - steden. For a broader overview of Dutch plural formation including irregularities cf. e.g. BOOIJ (2002:21-34), HAESERYN et al. (2'1997:165-184), and VAN HAERINGEN (1949). 
huis $+j e-s$ 'small houses'. Examples for this type of variation are listed in Appendix 3.

The first type of doublets can be observed in various cases. Often, doublets are found in a functional distribution distinguishing between different semantic notions of homonym stems (cf. HAESERYN et al. 1997:183-184). The word bal, e.g., is polysemous - as in English - for the meaning 'ball (toy)' and for 'ball (gala)'. The plural form ballen is used for the former meaning, the plural form bals mostly for the second. For other words which are not polysemous, but still have variable plural forms, the following tendencies have been described: The en-plural is more often used in written language, while $-s$ dominates in the spoken language. BoOIJ $\&$ VAN SANTEN (1998:97) claim that those forms which are not in accordance with the trochee principle have "a special character", while the trochee forms are unmarked. ${ }^{11}$

With reference to Kiparsky's account of blocking described in Section 1, both plural forms are equally economical (both forms consist of one stem + one suffix). Even though the forms in some cases bear different pragmatic connotations in use - such as higher formality with en-forms - both allomorphs can also be regarded as equally expressive, since they both fulfill their grammatical function of marking plural meaning to the same extent.

The doublets of the first type are remainders of earlier free competition between $s$ - and en-plurals. Due to the establishment of the prosodically-based condition favoring the allomorph which forms a trochee, one of the plural allomorphs was blocked in most instances. This conditioning thus forms a constraint even stronger than economy and expressiveness. Therefore, the number of doublets of this kind is now limited and no new nouns have developed this kind of double plural since the trochee condition was fully established. As type 1 is thus unproductive and limited, we focus only on type 2 in the following.

In contrast with the irregular doublets of type 1, doublets of type 2 are completely regular with respect to Dutch plural formation, i.e. according to the trochee condition, in both forms. In contrast with the doublets of type 1, new words of the specific structure - ending in a schwa - can also be expected to form plurals with both allomorphs without preference. We are thus dealing with non-blocking which - at least at first glance - is not constrained by any further condition in plural formation.

In the following section the history of Dutch plural formation is studied, with the aim of pointing out the reasons which led to the appearance and preservation of doublets. For this reason we will contrast the history of Dutch with that of two closely related languages, German and Afrikaans.

11 Since some dialects only possess one of the forms described (cf. DE ROOIJ 1974), the existence of doublets in Standard Dutch may also be related to geographical variation. 


\section{The emergence of (non-)blocking in contrast: The diachrony of Dutch, German, and Afrikaans plural allomorphy}

In contrast with Dutch, the standard languages of Modern German and Afrikaans are not characterized by doublets to a high extent, especially not with respect to nouns ending in a schwa. In German, instead, plurals of this group of nouns are usually formed with an $n$-suffix (cf. Bote- $n$ 'messengers'), whereas in Afrikaans an $s$-suffix is used (cf. bode-s 'messengers').

Both languages are closely related to Dutch: Dutch and German originate from the same branch of West Germanic. The neighboring languages constituted a common Low and Middle German dialect continuum in the early Middle Ages. Only when standardization came about in connection with nation building did the two distinct languages evolve into separate social units. Afrikaans is one of the youngest Germanic languages. Dutch colonists settled at the Cape in the $17^{\text {th }}$ century and kept speaking their Dutch dialects. From that point of time on, the language developed distinctly from Dutch with low-scale creolization effects. Many grammatical structures of Afrikaans are still very similar to Dutch, and the written languages are mutually intelligible to a high extent.

In the following, we will focus on the question of how plural doublets in Dutch arose, and what happened in German and Afrikaans in contrast with Dutch. An explanation will be sought in inner-linguistic factors.

\subsection{Dutch and German in contrast}

Dutch and German both belong to the West Germanic language subfamily. Some divergences between the Old High German and the Old Dutch (i.e. Old Low Franconian) dialects already occur in the oldest accessible documents, but generally the linguistic structures are still quite similar in these early stages. Plural formation clearly begins to diverge between the Old and Middle High German and Old and Middle Dutch periods, respectively. As the emergence of doublets is strongly connected with the parallel development of prosodic conditioning principles in both languages, it is the area of focus in the following first subsection. After that, a comparative view on the broad range of conditioning principles is provided in order to show other relevant factors.

\subsubsection{The emergence of prosodic conditioning principles}

Before actually focusing on the cases of interest, the necessary background information is to be provided by presenting general developments in the history of nominal plural marking in Dutch and German. The main point of interest is the reduction of zero plurals and the subsequent development of similar, but in detail slightly different output-based prosodic conditioning principles, because these constitute one of the most important factors for the preservation or loss of doublets. We will then come back to the emergence and development of plural doublets in the specific groups of nouns introduced in section 2 .

The historical developments sketched in the following are based on language histories and grammars. For German, central information stems from e.g. BRAUNE \& 
REIFFENSTEIN $\left({ }^{15} 2004\right)$, PAUl et al. $\left({ }^{24} 1998\right)$, and Wegera (1987). For Dutch, information is drawn from e.g. MARYNISSEN (1996), and VAN LOEY $\left({ }^{6} 1960\right)$.

\section{a) Background: Outline of the history of plural marking in Dutch and German}

In Old Dutch and Old High German, full vowels were not yet restricted to certain positions of the word, i.e. they occurred in stressed as well as unstressed syllables. Due to the strong first syllable accent in Germanic, vowels in unstressed syllables were mostly reduced in the further development of both languages, cf. e.g. Old High German geba > Middle High German gebe 'gift'.

In some declension classes, this had the effect that the forms of such prominent positions as nominative singular and nominative plural merged, i.e. the formal development resulted in syncretisms in morphological paradigms. This is the case with feminine $\bar{o}$-stems like geba, for example, cf. Old High German nom. sg. geba - nom. pl. geba $>$ geba - geba > Middle High German gebe - gebe 'gift'. The most prominent plural case and the most prominent singular case were now in zero opposition. ${ }^{12}$

Both in the history of Dutch and of German, most of the following developments can be interpreted as leading to the reduction or even loss of this newly established zero plural marking. In Dutch, all nouns with zero plural were transferred to suffixed classes. Figure 1 illustrates this in a schematized diagram of the developments in the biggest plural classes from Old Dutch to Middle Dutch.

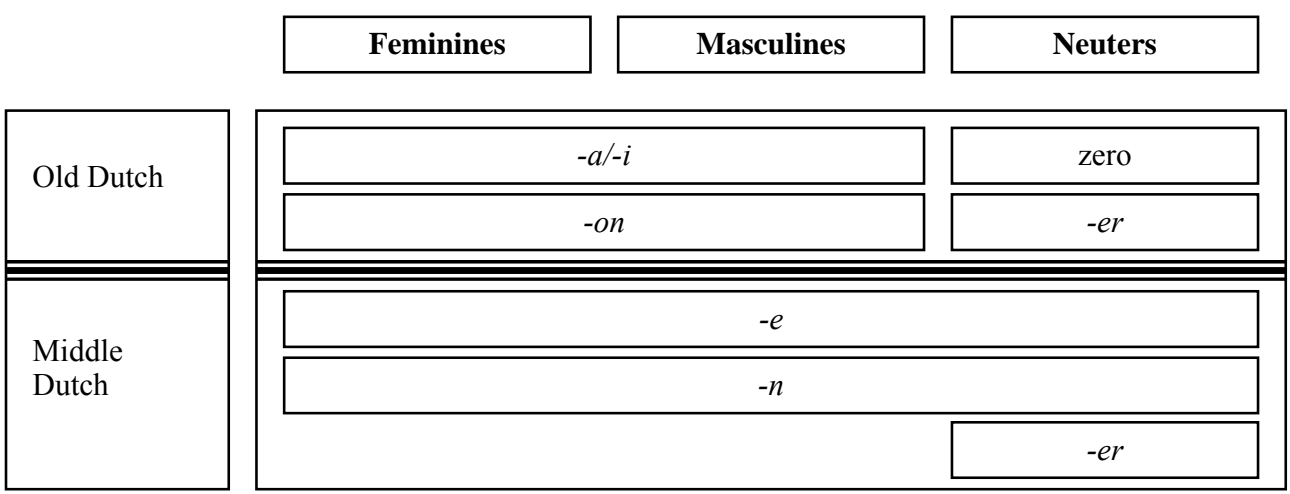

Figure 1: The reduction of plural allomorphy from Old Dutch to Middle Dutch

The diagram shows right away that a strong gender correlation, which established a border between neuters and non-neuters in Old Dutch, was abolished in Middle Dutch. The classes with $a$ - and $i$-suffixes, most characteristic with feminines and masculines, merged through vowel reduction. In this way, the number of big classes was reduced from three to two for non-neuters.

12 In the following the focus is on the contrast between nominative singular and nominative plural, which are considered the main number markers for the following reasons: In later stages of development - both in Dutch and in German - the fused case-number marking is separated. The newly emerging number markers are then reanalyzed based on the markers in the nominative positions. A notation of morphological contrasts which is indicated by a hyphen contrasts (nominative) singular forms with (nominative) plural forms in the remainder of this article, as e.g. in child-children. 
With regard to the neuters, neither of the two former classes obtained stronger productivity. The small class of neuters with er-plural, which consisted of c. 15 nouns (and still exists in Modern Dutch in the extended form -eren), was not extended at all. Neither did the zero class (the former neuter $a$-stems) maintain its high productivity. Instead, the nouns from this class were transferred to the two non-neuter classes, which had gained strongly in type frequency, cf. Old Dutch skuoi - skuoi- $\emptyset>$ Middle Dutch scoe - scoe-n 'shoe' and Old Dutch wort - wort- $\emptyset$ $>$ Middle Dutch wort - word-e 'word'.

The two remaining productive allomorphs were no longer conditioned by gender, but rather by the stem's final sound: $-n$ followed vowels, $-e$ consonants. As this system spread to all nouns, zero plurals were lost entirely.

A similar reduction of zero plurals can be observed in the history of German: All monosyllabic nouns with a zero plural were transferred into suffixed plural classes. In this way, the large zero plural class of strong neuter $a$-stems was transferred into the $e$ - or the er-class, cf. Middle High German wort - wort- $\emptyset>$ wort -wort-e/wört$e r$ 'word'. In addition to the monosyllabic stems, most of the feminine bisyllabic $\bar{o}$ stems were transferred into the weak feminine declension class, cf. Middle High German gebe - gebe- $\emptyset>$ gebe - gebe- $n$.

However, German also developed new zero plurals in some classes. The formerly differentiating plural-suffix was often apocoped on bisyllabic nouns ending in a combination of a schwa and a sonorant, cf. Old High German fingar - fingar-a $>$ Middle High German finger - finger-e $>$ finger - finger $-\emptyset$. While suffixation was made obligatory for all monosyllabic nouns and those bisyllabic nouns which ended in a schwa, a new zero marking was thus surprisingly accepted with the group of bisyllabic nouns ending in a consonantal sonorant.

\begin{tabular}{|c|c|c|c|c|}
\hline & OHG & MHG & MHG & NHG \\
\hline monosyllabic & wort $-\varnothing$ & wort- $\varnothing$ & wort- $\emptyset>$ wort-e/-er & \\
\hline bisyllabic & tag-e & tag-e & $\mid \begin{array}{l}\text { tag-e } \\
\text { finger- } \varnothing\end{array}$ & $\begin{array}{l}\text { Wört-er/Wort-e } \\
\text { 'words' } \\
\text { Tag-e 'days' } \\
\text { Finger- } \emptyset \text { 'fingers' }\end{array}$ \\
\hline trisyllabic & fingara & fingere $>$ finger- $\emptyset$ & & \\
\hline & OD & MD & MD & ND \\
\hline monosyllabic & $\begin{array}{l}\text { skuo-i } \\
\text { wort- } \varnothing\end{array}$ & $\begin{array}{l}\text { scoe- } n \\
\text { wort } \varnothing>\text { word-e }\end{array}$ & scoe- $n>$ scoen-en & \\
\hline bisyllabic & dal-e & dal-e & $\begin{array}{l}\text { word-e }(>\text { woord-en }) \\
\text { dal-e }(>\text { dal-en })\end{array}$ & $\begin{array}{l}\text { schoen-en 'shoes' } \\
\text { woord-en 'words' } \\
\text { dal-en 'valleys' } \\
\text { rechter-s 'judges' }\end{array}$ \\
\hline trisyllabic & rechter-en & rechter-en $>$ rechter-e & rechter-e > rechter-s & \\
\hline
\end{tabular}

Table 1: Emergence of trochee principles in plural formation in German and Dutch ${ }^{13}$

This development in German is caused by the emerging principle of bisyllabic, trochaic plural forms, as illustrated in the upper half of Table 1 . Whereas plural forms occurred in mono-, bi-, and trisyllabic form with considerable frequency in

$13 \mathrm{OHG}=$ Old High German, $\mathrm{MHG}=$ Middle High German, NHG = New High German, OD = Old Dutch, $\mathrm{MD}=$ Middle Dutch, ND = New Dutch. 
Old High German, in New High German most plural forms are bisyllabic, i.e. trochaic. This holds for both monosyllabic and bisyllabic (singular) stems.

In a first step of the development towards Middle High German, the emergence of a maximum syllable number for plural forms can be observed. Trisyllabic plural forms are mostly reduced, and new zero plurals occur with nouns ending in the schwa+sonorant-combinations -el, -en, or -er. The maximum syllable number seems to have higher priority than the reduction of zero plurals.

As a result, since the number of bisyllabic plural forms increases, the prosodic structure of trochees becomes more and more prominent for plural forms and gains influence on all other plural forms not conforming to this principle. Monosyllabic stems therefore become syllabically suffixed in the plural, so they form trochees as well.

In Dutch, a similar development can be observed in a later phase of Middle Dutch, cf. Table 1, lower half. At first, the Old Dutch zero plural class is transferred to the $e$-class. Then the $n$-plural on monosyllabic stems is abandoned in favor of a syllabic plural suffix. This often happens through reinterpretation of the plural- $n$ as belonging to the stem, cf. scoe - scoen > scoen - scoene ( $n)$ 'shoe'.

Trochaic plural forms obviously capture a dominant position in Dutch (cf. MARYNISSEN 1996:388), similarly to the developments in German. Consequently, the number of trisyllabic plural forms is reduced as well. But instead of establishing new zero plural forms as in German, a different solution is adopted in Dutch: The unsyllabic plural allomorph $-s$ is now used with these stems.

The $s$-allomorph was not a productive suffix in Old Dutch. Actually it only appears once in all available Old Dutch manuscripts, i.e. according to the sources of Old and Middle Dutch we deal with a new plural suffix. It first appears with the group of nomina agentis, which historically belong to the old ja-stems, cf. Middle Dutch rechters 'judges'.

This allomorph likely stems from a group of Ingwaeonic Dutch dialects which have kept the $s$-plural from the masculine $a$-declensions (cf. the discussions in PHILIPPA 1981, 1982). Generalizing from the fact that the nomina agentis-stems ended in -er, the appearance of the $s$-allomorph was then based on the formal condition of a final sound combination in -er, which was then further extended to all stems ending on schwa+sonorant-combinations, namely -el, -en, -em, and -er.

In this way, in contrast with German there was no new zero plural established with bisyllabic nouns in Dutch. Instead, another unsyllabic allomorph was used, and it increased strongly in productivity, giving support to the new condition of suffixed bisyllabic plural forms in the whole noun lexicon. As in German, an output principle of trochaic plural forms was established.

The further development of Dutch reveals another major change: After a new plural allomorph had arisen in the form of the s-suffix, the number of plural allomorphs was reduced once more through the loss of the $e$-suffix. At the same time, a new, syllabic variant for the $n$-suffix is established. Two productive suppletive allomorphs remain, the (e)n-and the $s$-suffix.

Different theories exist with respect to this development (cf. VAN LOEY $\left.{ }^{6} 1960: 100\right)$ : On the one hand, the en-suffix can possibly be analyzed as a generalization of the dative-plural-suffix, which had been $-n$ in all paradigms. On the other 
hand, we could be dealing with the emergence of a syllabic variant of the $n$ allomorph which already existed, leading to a generalization of $-(e) n$ where the $s$ suffix did not apply.

The result of these developments is the plural system of Modern Dutch, with two suppletive allomorphs $-(e) n$ and $-s$, one of which consists of two phonological allomorphs in a syllabic and an unsyllabic form, -en and $-n$.

The plural systems of Modern Dutch and New High German are thus both characterized by a trochee principle for plural formation. In the further development of German this principle is even overruled by a superior principle which is called the "reduced syllable plural" (NEEF 1998), i.e. plural forms are characterized by ending in a reduced syllable. Even if they are bisyllabic and trochaic, nouns which do not end in a reduced syllable are for this reason suffixed with a marker constituting a reduced syllable, cf. Teppich - Teppiche 'carpet'. ${ }^{14}$

The difference between the pure trochee plural of Dutch and the reduced syllable plural of German becomes obvious on nouns with possible stress shift, like German Motor 'motor' or Professor 'professor'. These are always suffixed with -en because of the reduced syllable plural, cf. (3a). In contrast, because for Dutch motor and professor the trochee plural is the only and superior principle of plural formation, both the unsyllabic $s$-plural and the syllabic en-plural can appear, the only condition being that the stress of the stem is set at the correct place to form a trochee (cf. 3b).

$$
\begin{array}{lll}
\text { a German } & \text { Mótor-Motór-en } & \text { Proféssor-Professór-en } \\
\text { b Dutch } & \text { mótor-mótors/motór-en } & \text { proféssor-proféssor-s/professór-en }
\end{array}
$$

\section{b) Output-based plural marking and plural doublets}

On the basis of this outline of the history of plural formation in Dutch and German, we can now return to the questions of why regular plural doublets are observed in Dutch in contrast with German.

In principle, the examples in (3) indicate why the system of Dutch plural formation is so flexible: The only (prosodic) condition for plural forms is the formation of trochees, and doublets may come up whenever this condition is fulfilled by more than one allomorph. The German system is not that flexible, however, having the superior condition that the plural form needs to end in a reduced syllable.

Those cases which constitute the main focus, the nouns ending in a schwa, are now to be addressed. In German, most bisyllabic nouns ending in a schwa resulted from the $\bar{o}$-class and the weak $n$-stems. As early as the Middle High German period, all these nouns gathered in a homogeneous declension class with $n$-plural (see above).

In Middle Dutch more or less all nouns ending in a vowel are characterized by an $n$-plural, and so are the nouns ending in a schwa. Nonetheless, in the further development of Dutch the s-plural becomes highly productive, and begins spreading to

14 This does not hold for nouns ending in a full vowel, which are uncommon in German and accordingly take the plural marker for atypical nouns, namely $-s$, cf. Tempo - Tempos 'speed', Oma Omas 'grandmother'. 
all nouns which fulfill its criterion for appearance - by ending in an unstressed syllable so a trochee plural can be built.

The stems ending in schwa+sonorant-combinations thus lost their syllabic plural in favor of the unsyllabic s-plural. But the nouns ending in a schwa, which had a trochaic plural in $-n$ before, also met the criteria for the $s$-plural. Since both $-s$ and $n$ are unsyllabic and therefore well-suited to form a trochee plural, this results in competition between both unsyllabic plural suffixes on stems in schwa.

In conclusion, one reason for the fact that productive plural doublets came up in Dutch is the output condition of trochee plurals, combined with the fact that a new unsyllabic allomorph gained strongly in productivity on stems on which another unsyllabic suffix was yet in use. In German, output principles have come up in a similar fashion, but in contrast with Dutch, no doublets emerged on nouns in schwa since there was no competing unsyllabic suffix.

\subsubsection{Conditioning principles in Dutch and German}

In the last section, the parallel emergence of prosodic conditioning principles for plural allomorphs has been shown. At the same time it became clear that differences between the Dutch and German plural systems occurred. In this section the effects the parallel and divergent developments had on the plural systems of Modern Dutch and Modern German are addressed.

The most remarkable divergence between the two languages is the difference in the number of plural allomorphs. In Dutch the number of suppletive allomorphs was reduced to three, two of which are still productive. German, by contrast, has a high number of productive allomorphs, with $-(e) n$, zero, $-e,-e$-umlaut (i.e. $-e$ in combination with umlaut, cf. Grund - Gründe 'reason'), and -s. There is also a frequent allomorph which has lost productivity: -er (when possible in combination with umlaut) appears with c. 100 nouns, most of which are highly token frequent, cf. Kind - Kind-er 'child' or Haus - Häuser 'house'. ${ }^{15}$ Umlaut without additional suffixation is also found - as in Garten - Gärten 'garden' - but is no longer productive.

The languages also differ strongly with respect to conditioning principles. The German conditioning is rather complex, in accordance with the high number of allomorphs to be conditioned, while in Dutch, there are no dominant conditioning principles apart from the main prosodic criterion of building a trochee plural.

The main difference is established in connection with the abandoning of gender conditioning in Dutch: In the development from Old to Middle Dutch, the conditioning of the two remaining allomorphs is based on formal grounds, as shown in the previous section. German, instead, preserves a conditioning based on gender for the high number of allomorphs remaining in Middle High German. This conditioning is even strengthened: The (e)n-suffix is mainly connected with feminine gen-

15 In Dutch, 15 neuter nouns have preserved the plural formation in -eren, in which the productive suffix -en has been added to the old and unproductive suffix -er (cf. Appendix 1). These 15 nouns are highly token frequent. Still, in German the number of nouns with an er-plural is much higher, and this allomorph has also spread to masculines, which shows that it has had a higher productivity than in Dutch. 
der, while masculines and neuters are characterized by sharing all other plural allomorphs.

The resulting conditioning system in New High German is dominantly based on gender and prosody. The gender criterion mainly conditions the suppletive allomorphs, while the phonological allomorphs are distributed with respect to the prosodic criterion. Even the suppletive allomorphs $-e$ and zero are distributed according to the trochee principles as phonological variants. Monosyllabic stems take the $e$-suffix (Hund - Hund-e 'dog'), while bisyllabic stems appear with zero marking (Engel - Engel- $\emptyset$ 'angel'). In this way, these two allomorphs are combined into one suppletive allomorph -(e). The same holds for the umlaut variants, the allomorph being -(e)-umlaut, cf. Grund - Gründe 'reason', Garten - Gärten 'garden'.

\begin{tabular}{|c|c|c|c|c|}
\hline & \multicolumn{2}{|c|}{ Prosody (phonological allomorphs) } \\
\hline & & & Monosyllabic & Bisyllabic \\
\hline \multirow{4}{*}{ 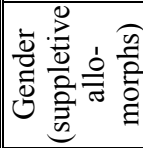 } & Feminine & $-(e) n$ & -en: Schlacht-en 'wars' & -n: Tasche- $n$ 'bags' \\
\hline & \multirow{3}{*}{$\begin{array}{l}\text { Masculine } \\
\& \text { Neuter }\end{array}$} & $-(e)$ & -e: Hund-e (m). 'dogs' & - Ø: Engel- $\varnothing$ (m.) 'angel' \\
\hline & & $-(e)$-uml. & -e-uml.: Gründ-e (m.) 'reason' & -Ø-uml.: Gärten (m). 'gardens' \\
\hline & & $-e r$ & -er: Kind-er (n.) 'children' & - \\
\hline
\end{tabular}

Table 2: Schematized plural allomorph conditioning in New High German

Table 2 describes the New High German plural system. ${ }^{16}$ In contrast with the complex conditioning structures of German, the Dutch system can be explained without a table: Finally stressed nouns take $-e n$, nouns with non-final stress $-s$ or $-n$. Within the group of nouns with non-final stress, nouns ending in a consonantal sonorant or in -je only take $-s$. The Dutch system turns out to have reduced complexity to a high extent, in the number of allomorphs as well as in the number and quality of conditioning principles.

With respect to the emergence of plural doublets, it seems that this reduction of complexity in the plural system has made it possible to keep plural doublets in the system. In German the productive appearance of allomorphs is strongly conditioned by several structural properties of the stem. Despite their high number, German plural allomorphs are well-distributed. In Dutch, the number of allomorphs is much lower, but since the conditioning has been reduced to only one dominant principle, it is more variable than in German. After all, the reduction of system complexity proved to be a window of opportunity for plural doublets to stay, because no other dominant conditioning factor - such as gender in German - is retained to determine the distribution of the unsyllabic allomorphs $-s$ and $-n$ on nouns in schwa.

\subsection{Dutch and Afrikaans in contrast}

The Dutch-German comparison reveals strong differences in plural formation. By contrast, Afrikaans plural formation is very similar to that of Dutch. This is due

${ }^{16}$ In fact, the gender conditioning is not as strict as indicated here: Weak masculines, e.g., appear in a special declension class with (e) $n$-markers, and c. 35-40 feminines bear the $e$-umlaut-plural. Additionally, some subclasses are sensitive to semantic and morphological conditioning factors. Due to space limitations, they cannot be treated in this article. 
to the fact that Dutch plural formation was already reduced in complexity to a considerable degree when Afrikaans began to develop independently.

The starting point of the independent development of Afrikaans is Early Modern Dutch. In the $17^{\text {th }}$ century, Dutch tradesmen settled at the Cape and built a colony where they continued using their dialectal varieties. The language also spread to native inhabitants, which was followed by some low-scale creolization effects.

Much like German, hardly any regularly-conditioned plural doublets are found in Afrikaans. Since Afrikaans also differs from Dutch in this respect, historical developments of Dutch and Afrikaans are now considered in contrast.

In large parts of the Dutch dialect area, apocope of final $-n$ can be observed. This is also true for the standard variety in these areas. Still, as part of the plural allomorph $-(e) n$, the $-n$ is sometimes realized even in apocoping areas, either when formal articulation is wished, or - for linguistic reasons - before a following vowel-initial word, when a hiatus is avoided (cf. HAESERYN et al. 1997:167). This shows that Dutch-speakers still have knowledge of the $/ \mathrm{n} /$ in plural formation, even though it is most often apocoped in realization. In this way, competition between unsyllabic $-n$ and $-s$ was retained.

By contrast, the apocope of final $-n$ spread over the whole linguistic system of Afrikaans. This is also true for plural formation, which at first glance is very similar to that of Dutch: There are two very frequent and productive allomorphs of which $-s$ is formally identical with the same allomorph in Dutch, whereas $-e$ is the apocoped form of the Dutch en-allomorph.

In addition, a variant of the $e$-allomorph emerges in the form of -te: In stems ending in $-s t$ and other consonant clusters in $-t$, the stem was reduced due to apocope of final $-t$ in word-final clusters (cf. PONELIS 1993:185). In plural forms, however, the onset- $t$ was reanalyzed as being part of the plural allomorph, cf. beest - beest-e $>$ bees - bees-te 'cow' or nagt - nagt-e > nag - nag-te 'night'. In spoken Afrikaans, the new suffix then spread to other words, most of which end in $-s$, cf. bos boste 'bunch', klas - klaste 'class' etc.

As in Dutch, double suffixes have been preserved in a small number of nouns. These occur not only in the form -ere - the equivalent of Dutch -eren (cf. liedere 'songs', volkere 'peoples') - but also in -ers, which occurs in a wide range of Dutch dialects as well, cf. kinders 'children', lammers 'lambs'. This allomorph has also spread to a small number of other stems, cf. maters 'pals', klippers 'stones' etc.

In the history of Afrikaans, as in Dutch, there has been competition between $-s$ and $-e$, which in the $18^{\text {th }}$ century was still rather unsystematic. Regularization can be observed in the development to present-day Afrikaans. It resulted in a reduction of plural doublets such as hotels vs. hotelle 'hotels' or gewere vs. geweers 'rifles'.

The distribution of the syllabic vs. unsyllabic suffixes in current Afrikaans is described in a clear-cut account by RAIDT (1983:129-133), who identifies the stress position in the stem as main conditioning criterion: Stems with word-final stress take the syllabic $e$ - or te-suffixes, cf. monosyllabics as boek - boeke 'book', huis huise 'house', finally stressed polysyllabics as beróép - beróépe 'profession', kamél - kaméle 'camel', and stems ending in suffixes which have (or have had) phonological word status such as leerling - leerlinge 'apprentice', begrafnis - be- 
grafnisse 'funeral'. The $s$-suffix appears mainly with polysyllabic stems ending in an unstressed syllable, cf. bode - bodes 'messenger', appel - appels 'apple', and also in unstressed suffixes which do not have phonological word status, cf. sondaar - sondaars 'sinner', dikkerd-dikkerds 'thick person'.

From this distribution it is concluded that the main conditioning rule for plural allomorphs in Afrikaans is the same as in Dutch, namely that the plural form should end in a trochaic foot. Further evidence for this can be found in the fact that, much like in Dutch, plural doublets remain in some stems with variable stress, $\mathrm{cf}$. professóre vs. proféssors 'professors' and lektóre vs. léktors 'lecturers'.

Of course, as is expected, exceptions to this rule are also found. As in Dutch, terms for persons, especially kinship terms, often appear with $s$-plural despite being finally stressed, cf. oom-s 'uncles', seun-s 'sons'. Some borrowed derivational suffixes with final stress regularly appear with $s$-plural as well, cf. -eur in akteur-s 'actors', or -ier in juwelier-s 'jeweler'.

The overall picture is that of a trochee plural system strongly comparable to that in Dutch. Nevertheless, much fewer doublets are observed in Afrikaans than in Dutch. Especially in the case of nouns ending in schwa, no variation whatsoever is found in Afrikaans. All nouns of this structure take the same suffix, namely $-s$, cf. groente-s 'vegetables', geliefde-s 'lovers', gesteente-s 'rocks' etc.

The historical reason for this is the following: Through the apocope of final $-n$, the suffix $-(e) n$ was reduced to $-(e)$. While the syllabic form appears as a schwa, this suffix establishes zero plurals when the stem already ends in a schwa. In parallel with Dutch, zero plurals are avoided in Afrikaans. Since the $s$-suffix spread to other trochaic nouns, it could also easily be used with stems in schwa, as it is in Dutch. But in contrast with Dutch, there is no competing unsyllabic allomorph $-n$, which would make blocking necessary. The main reason for the strong reduction of the number of plural doublets in Afrikaans is therefore the reduction of allomorphy due to general $n$-apocope, which resulted in only one unsyllabic suffix. This suffix could spread to all stems to which it was applicable.

\subsection{Summary}

In the above section it has been shown that two factors separated Dutch from the two contrasted languages:

a) In contrast with German and Dutch, the apocope of final $-n$ shapes all wordforms in Afrikaans, while it is restricted by certain conditions in Dutch and not applicable in Standard German.

b) Both Dutch and Afrikaans fully phase out zero plurals. German, by contrast, retains zero plurals with some nouns already ending in a reduced syllable. The question of why German differs from the other languages in this respect cannot be answered sufficiently. We can only speculate about two factors which play a role in the reduction of zero plurals:

i) Plural information belongs to the highly relevant inherent morphology of nouns and therefore generally tends to be marked on the noun instead of the surrounding syntax according to BYBEE's (1985) relevance principle.

ii) When the information is marked on agreement targets in the surrounding syntax, however, zero marking may not cause any problems. A comparison of plural 
marking in the surrounding syntax and additional noun morphology in four Germanic languages in KÜRSCHNER (2008:245) shows that the more a language has reduced zero plurals, the less it has retained redundant plural marking through agreement in the surrounding syntax or in additional morphology. ${ }^{17}$ Still, this is a problem of what comes first, the chicken or the egg. We do not know if the reduction/preservation of zero plurals causes the loss/extension of plural marking on agreement targets, or if on the contrary extension or loss of plural marking on the agreement targets causes the reduction or obligatory marking of plural on nouns.

Two decisive circumstances for the absence/presence of morphological blocking can be described in connection with factors a) and b):

Number of allomorphs: While the German plural allomorphy remains highly complex by retaining a high number of allomorphs, this complexity is reduced considerably in Dutch and Afrikaans. This is particularly clear in Afrikaans, which exhibits only a single unsyllabic plural formative.

Number and quality of dominant conditioning principles: The number of allomorphs is strongly connected with the number of principles of primary distribution. In retaining a complex conditioning mainly based on gender and prosody, the high number of allomorphs in German is mostly regularly distributed. In Afrikaans, only one dominant conditioning factor, that of a trochee plural, is sufficient for the low number of allomorphs. In Dutch, the same conditioning factor cannot capture all the allomorphy, as two unsyllabic allomorphs remain. This is why varying plural formation occurs with stems in final schwa.

\section{Morphological non-blocking in Dutch: Explanations from an output perspective}

From contrasting the histories of plural formation in Dutch, German, and Afrikaans, the number of allomorphs and of the conditioning principles for allomorphs could be identified as crucial criteria for the (non-)establishment of morphological blocking. Nevertheless, these varying circumstances are accompanied by a common characteristic of the three languages: They all develop output-based allomorph conditioning in the course of their history.

In this section, the output principles are considered as a crucial factor for the establishment of (non-) blocking. To be more precise, an account of cases that fail to exhibit blocking effects will be presented. To test this account, some conditioning factors claimed to govern a new distribution of $-n$ and $-s$ with stems in final schwa in Dutch are taken into consideration.

Output principles involved in the three languages are considered first, and a synchronic view on the three languages is employed on the basis of their current statuses. In all three languages, plural formation is most often characterized by the formation of trochaic feet. In German the factor of ending in a reduced syllable is

17 In fact, the Scandinavian languages such as Danish and Swedish, which retain zero plurals to a high degree, are characterized by a morphological definiteness/number-suffix, which, when applicable, also marks number, cf. Swedish hus 'house' hus-et 'the house' - hus- $\emptyset$ 'houses' - hus-en 'the houses'. 
predominant, but trochees are most frequent in this case as well. Following from this, all three languages not only mark the plural through special segmental endings, but also through a specific prosodic structure marking morphologically complex word forms.

Some examples from investigations in German plural formation may illustrate this: On the basis of Schema Theory (cf. BYBEE 1988), KÖPCKE (1993:88-89) describes German plural formation by using a range of prototypes which are based on singular-plural-oppositions. These 'schemas' are ordered on a scale. The strongest singular schema is found in a monosyllabic prototype, the strongest plural schema in a bisyllabic - and trochaic - prototype. ${ }^{18}$

Generalizing on the basis of the reduced syllable plural, a prototypical singular form is associated with final stress, while plural forms are prototypically associated with ending in a reduced syllable, which is always unstressed in German. Additionally, there is a segmental condition saying that the plural allomorph must end in a sonorant. ${ }^{19}$

These singular and plural prototypes are motivated through their high frequency in the lexicon of German, through the historical development resulting in more and more singular and plural forms of the prototype kind in the lexicon, and also through the results of psycholinguistic experiments reported in KÖPCKE (1993:183203). Of course, a description based on prototypes allows for exceptions which do not conform to this principle. On this basis, the considerable number of stems in bisyllabic singular forms (like Schlüssel 'key' or Tasche 'bag') is also part of the description. They only deviate from the strongest schemas in their singular form.

Based on a schema theory like this, plural formation is not only connected with specific segments, as it has been described in more traditional, purely rule-based accounts. Plural formation is instead described on the basis of highly general prototypical features which are based on prosody. The idea behind this description is that language learners and users get used to the association of formal singular prototypes with singular meaning, and plural prototypes with plural meaning, by way of language reception. Lexical connections are made by connecting specific prosodic forms with meanings and abstracting prototypes from these associations (cf. BYBEE 1988).

The description with schemas can easily be adapted to Dutch and Afrikaans. The noun lexicons of these languages can even be described as much more homogeneous than that of German: Singular forms are prototypically monosyllabic and end in a stressed syllable. Plural forms, by contrast, are prototypically polysyllabic and end in a trochaic foot. Additionally, Dutch and Afrikaans plural forms are associated with a deviation from the stem form, which is formed by adding a segmental ending. NEEF (1998:256) has described this kind of condition as a "Design Condition of Difference to the Base", which in German is only valid for the special class of $s$-plurals, but in Dutch and Afrikaans characterizes the whole noun lexicon.

18 Köpcke also includes information about the segmental form of the plural suffixes and about the form of the determiner, which are not considered in this summary.

19 Nouns ending in a reduced syllable with final obstruent, by contrast, do not signal the plural sufficiently. Here, a syllabic suffix is added, cf. Abend-e 'evenings', Kirmess-en 'fairs'. 
Summing up, the prototypical plural schema in Dutch and Afrikaans consists of a) ending in a trochaic foot, and b) the condition that when the final segment is deleted ${ }^{20}$ the remaining combination of sounds must correspond to a noun stem in the lexicon. Based on these singular and plural prototypes, an easy description of Dutch and Afrikaans noun morphology is possible.

Taking a schema theory as the basis of an account of morphological blocking, one would expect morphological blocking to be established in the change of plural formation when an allomorph does not fulfill the prototypical plural schema. In Dutch as well as in Afrikaans, this has actually happened with most of the nouns employing a plural allomorph which does not form a trochaic foot together with the stem. Only highly lexicalized plural forms which deviate from the trochee principle remain in both languages without inducing blocking effects (cf. kok-s 'cooks', engel-en 'angels'; cf. also Appendix 1 and 2 for doublets).

Still, as shown in section 2, the Dutch plural schema also makes it possible for doublets to be retained in Dutch. Competition between $-n$ and $-s$ has come up on stems which end in a schwa. The crucial circumstance for non-blocking in Dutch is that neither of the unsyllabic allomorphs is preferred based on the trochee conditioning.

Nevertheless, this competition is only encountered with the specific groups of nouns in schwa. How can we explain that no doublets occur on other bisyllabic stems in Dutch? According to KIPARSKY (2005), free variation of allomorphs is only found when they are equally expressive and economical. In principle, both $-n$ and $-s$ are equally expressive (both serve to express the same function of plural to equal extents) and economical (both establish exactly one suffix).

However, taking different groups of stems into account, qualitative differences can be observed for the allomorphs: First of all, note that for stems ending in a sonorant, the sonorant $n$-suffix is equally sonorant as the final sound. Especially with nouns ending in -en (leugen 'lie') and -em (bliksem 'lightning'), an $n$-suffix would not be sufficiently distinct from the final sound for this reason, while the $s$ suffix is non-sonorant and therefore sufficiently different from the stem. Accordingly, stems ending in a consonantal sonorant are suffixed by $-s$ to avoid the danger of poorly perceptible or zero plurals.

Taking stems ending in schwa into account, in contrast, both suffixes are highly distinct from the final sound and therefore clearly perceptible - assumed that $n$ apocope is either omitted or generally abstracted for by Dutch speakers, as described above. ${ }^{21}$ With this group of nouns, no qualitative principle can be found to make one of the suffixes preferable. As a consequence, no blocking for either of the allomorphs is established, as both suffixes are equally expressive and economical, both serve to create outputs in accordance with the plural schema in Dutch, and no additional constraining conditioning is accounted (as is the case with nouns ending in a consonantal sonorant). Instead, both allomorphs exist in free variation.

${ }^{20}$ Only the final segment needs to be deleted, i.e. both Afrikaans and Dutch are characterized by a principle of minimal plural marking through exactly one segment (cf. MARYNISSEN 1996:386).

21 Of course, it may be argued that both suffixes are generally of different salience, e.g. through their different consonantal strength. My point is only that they are both well suited as plural suffixes in the cases taken into account here. 
Having explained non-blocking in Dutch, how can we explain that the two other languages do not exhibit regular non-blocking? The difference between Dutch and Afrikaans emerges because no competition between unsyllabic allomorphs is encountered in the history of Afrikaans as it is in Dutch. Since $n$-apocope shapes the system of Afrikaans more consistently, the only solution was to use $-s$ as the unsyllabic allomorph.

In German, the high number of allomorphs makes it impossible to predict a correct plural allomorph only on the basis of the output principle established by the reduced syllable plural. Nevertheless, when taking gender into account, a second principle of allomorph conditioning is found to determine the distribution of the suppletive plural allomorphs.

Gender differentiation between feminines on the one hand, and masculines and neuters on the other seems to build more general principles: Gender schemas are established along with number schemas. For example, feminines are generally associated with stems ending in a schwa. (This prototype actually deviates from the most important singular schema saying that a singular form should end in a stressed syllable.) Also, feminines generally differ from their base in the plural form, a fact often motivated by the observation that the definite article with feminines does not differ in number, cf. nom. sg. die - nom. pl. die, whereas it does with masculines (der-die) and neuters (das - die).

It seems that the gender schemas in German are as strong as the number schemas, and both of these equally shape the system of plural formation. In this way, the high number of allomorphs in German is paralleled by a high number of conditioning principles. Blocking is established along these lines. For example, the (e)nplural is strongly connected with feminine gender and therefore not generalized to an extent comparable with Dutch.

Thus, Dutch is different from Afrikaans in its less consistent $n$-apocope, and therefore retains plural doublets. German is different from Dutch because of a complex schema interaction, including number as well as gender schemas. Dutch has only one schema which in contrast with German makes it possible for regular plural doublets to stay.

I have sketched an output-based account of premises for morphological nonblocking. This account is challenged by the fact that newly occurring distributions for the competing allomorphs have been described in research on Modern Dutch plural formation. For example, ROYEN (1977:22) indicates that the $s$-plural is blocked in favor of the $n$-plural with nominalized participles, cf. gevangene- $n$ 'prisoners'. Also, a difference between de-adjectival nominalizations on -te (abstracts) and -e (usually human denotations) has been observed. While the abstracts tend to block the $n$-plural (hoogte- $n>$ hoogte-s 'heights', VAN DER HORST \& VAN DER HORST 2000:321), the forms in $-e$ are more often found with $n$-plural (cf. blinde- $n$ 'blind people'). Also, VAN HAERINGEN (1949:201) points out that a final schwa used as a derivational suffix for establishing female denotations like in student $+e$ 'female student' is always to be found with the $s$-suffix. In this way, the plural form for females like student $+e-s$ is differentiated from the corresponding male (or sexually neutral) forms as student-en. 
Some of these distribution rules have been challenged in the literature (cf. e.g. VAN MARLE 1987 for a critique of the rule which allegedly governs the distribution of forms such as studente-s vs. student-en). But if these distribution rules are true, they mainly serve to differentiate between some groups of closely related derivates, cf. zieke-n 'ill people' vs. ziekte-s/-n 'illnesses'.

With respect to non-derived stems, free variation is still encountered in most cases, cf. type-s/type-n 'types', schade-s/schade-n 'damages', vitamine-s/vitamine$n$ 'vitamins', bode-s/bode-n 'messengers', collecte-s/collecte- $n$ 'collections' and other examples in Appendix 3. This means that even if the formation of a new distribution is observed for subgroups of the nouns ending in a schwa, blocking effects are not established in general.

As we have seen, doublets have existed in Dutch plural allomorphy for a long time and they continue to exist in the special case of nouns ending in a schwa. These facts leave us in doubt about the assumption that morphological blocking actually has to occur. KROCH'S (1994:181) view that morphological doublets are "diachronically unstable" in general is contradicted by the doublets in focus. When seen from a prosodically-based output perspective, the two "competing" segments express plural equally well because both of them fulfill the main criterion of establishing a prosodic foot. Segmental doublets can be totally stable from this point of view.

All this taken into account, one doubt still remains about the identical qualitative status of both segments. $-n$ in word-final position is apocoped in large region of Dutch-speaking areas. Although $-n$ is realized in cases where the plural information is in danger and we therefore may suppose that users have knowledge of the $/ \mathrm{n} / \mathrm{cf}$. section 3.2), $-n$ still seems to be a "riskier" allomorph to express the plural information than $-s$. Although the studies examined reveal no signs of a development similar to that found in Afrikaans ( $-n$ is even conditioned more reliably with specific derivate groups, which makes its reduction unlikely), more detailed corpus studies of spoken and written Dutch - preferably including a diachronic component - are desirable in order to show whether the status of both allomorphs really remains stable.

\section{Conclusions}

The subject of this paper has been plural allomorphy in Dutch, with a focus on the special phenomenon of plural doublets. It was shown that plural doublets are retained with a group of nouns characterized by the common phonological feature of ending in schwa, whereas a complementary (or at least much more clear cut) distribution of plural allomorphs is observed with other nouns. In comparison with the histories of German and Afrikaans, it was shown that Dutch establishes an output-based plural formation, which is mainly characterized by plural forms ending in a trochaic foot - the same goes for Afrikaans. In German, plural forms most often end in a trochaic foot as well, but the more general common principle is that they must end in a reduced syllable. All three languages are thereby commonly characterized by prosodic output principles governing their plural formation. 
Both German and Afrikaans have reduced plural doublets over the course of history through morphological blocking, while Dutch retains morphological variation in the cases described above. It was found out that this is due to the fact that Dutch retains two unsyllabic allomorphs, but only one dominant distribution rule for them. By contrast, a much broader range of allomorphs is preserved in German. These are additionally conditioned through the gender information and well distributed through an interaction of plural and gender schemas. Afrikaans loses one of the allomorphs corresponding to the Dutch $-n$ due to the regular sound change of $n$-apocope.

In Dutch, the two unsyllabic allomorphs $-n$ and $-s$ are equally economical and expressive with nouns ending in a schwa. In this case, both forms with $n$-plural and with $s$-plural conform perfectly to the plural output schema, which is characterized by the condition of ending in a trochaic foot and by the condition that the plural stem needs to be formally different from the base. Both outputs therefore contain all the necessary signals for a plural form. Since no additional preference principle can be found, this constellation results in non-blocking.

It remains an open question whether a preference for the $s$-plural is slowly becoming established because the $n$-plural is in a highly apocope-endangered position. Detailed corpus studies dealing with this question are therefore desirable.

\section{Appendix}

Appendix 1: Nouns belonging to category (1b) listed in HAESERYN et al. (1997:165-184)

en-plural:

bacteri-ën 'bacteria', christen-en 'christs', engel-en 'angels', heiden-en 'heathens', heuvel-en 'hills', lauwer-en 'laurels', pori-ën 'pores', raadsel-en 'riddles', regel-en 'rules', teken-en 'signs', vinger-en 'fingers', vogel-en 'birds', water-en 'waters', wonder-en 'wonders'

$s$-plural:

broer-s 'brothers', boetiek-s 'boutiques', bougie-s 'candles', bruidegom-s 'grooms', bureau-s 'offices', café-s 'cafés', chef-s 'chefs', cheque-s 'cheques', club-s 'clubs', depot-s 'depots', chalet-s 'castles', etui-s 'cases', film-s 'movies', generaal-s 'generals', kok-s 'cooks', kolonel-s 'colonels', milieu-s 'environments', oom-s 'uncles', paraplu-s 'umbrellas', parfum-s 'perfumes', perron-s 'tracks', restaurant-s 'restaurants', reüníes 'reunions' roman-s 'novels', set-s 'sets', shirt-s 'shirts', ski-s 'skis', tank-s 'tanks', trottoir-s 'pavements', truc-s 'tricks'

(e)nen-plural:

leerrede-nen 'sermons', lende-nen 'loins' (regular sideforms: leerredes, lenden)

eren-plural:

beenderen 'legs', bladeren 'leaves', eieren 'eggs', gelederen 'joints', gemoederen 'dispositions', goederen 'estates', hoenderen 'chicken', kalveren 'calves', kinderen 'children', klederen 'clothes', lammeren 'lambs', liederen 'songs', raderen 'wheels', runderen 'cattle', volkeren 'folks', (there are regular side-forms: benen, bladen, kleden, and volken)

There are also some derivative suffixes which can sometimes be found with non-conforming plural formation, cf. -aar in schakelaar-s 'switches', -oir in reservoir-s 'reservoirs', -eur in amateur-s 'amateurs', -ier in portier-s 'porter', -oor in majoor-s 'majors', but some words with these suffixes have en-plural or belong to category (1c), see below. 
Loan words ending in a full vowel usually appear with s-plural even if this is not in conformity with the trochee plural (see some examples in the category "s-plural").

Appendix 2: Nouns belonging to category (1c), -s vs. -en, listed in HAESERYN et al. (1997:165-184)

Plural forms with a semantic distinction:

ballen 'balls (toys)' - bals 'galas', centen 'cent-pieces' - cents 'cents (calculation unit)', harmoni-ën 'harmonies' - harmonie-s 'music societies', hemel-en 'heavens' - hemel-s 'bed capony', koloni-ën 'colonies (of a country)' - kolonies 'colony (other meanings)', letter-en 'faculty of arts' - letter-s 'letters', mat-en 'measures' - maat-s 'mates', middel-en 'means' - middels 'waists', oli-ën 'oils' olie-s 'share of oil', patron-en 'cartridges' - patroon-s 'patrons', plann-en 'plans' - plan-s 'sketches', portier-en 'car doors' - portier-s 'porters', reden-en 'reasons' - reden-s 'relationships', stripp-en 'stripes' - strip-s 'comics', stukk-en 'pieces' - stuk-s 'exemplars', test-en 'pails' - test-s 'tests', tippen 'tail ends' - tip-s 'tips', vader-en 'ancestors' - vader-s 'fathers', vizier-en 'visors' - vizier-s 'viziers', wapen-en 'weapons' - wapen-s 'coats of arms', wortel-en 'carots' - wortel-s 'roots'

Plural forms without a semantic distinction:

aardappel 'potatoe', ader 'vein', ambtenaar 'civil servant', administrateur 'administrator', admiraal 'admiral', appel 'apple', artikel 'article', assuradeur 'assurance seller', assurantie 'assurance', beoefenaar 'person tackling with something', beoordelaar 'evaluator', ceremonie 'ceremony', concours 'bankruptcy', dienaar 'servant', directeur 'headmaster', duel 'duel', eigenaar 'owner', euvel 'illness', evangelie 'gospel', grammofoon 'gramophone', handelaar 'salesman', hazelaar 'hazel', historie 'history', individu 'individual', kandelaar 'candelabrum', karamel 'caramel', keu 'cue', knecht 'servant', lelie 'lily', maatregel 'regulation', mossel 'mussel', officier 'officer', ooievaar 'stork', provincie 'province', redacteur 'editor', residu 'residues', revenu 'income', sergeant 'sergeant', studie 'study', superieur 'superior person', tralie 'bar', tram 'streetcar', zondaar 'sinner', zoon 'son'

Appendix 3: Nouns ending in schwa

Nouns which belong to category (1c), $-s$ vs. $-n$, listed in HAESERYN et al. (1997:165-184)

bode 'messenger', collecte 'collection', gemeente 'municipality', geraamte 'sceleton', groente 'vegetable', kade 'quay', type 'type', vitamine 'vitamin', ziekte 'illness'

With semantic distinction: rede-s 'anchor places' - rede-n 'speeches'

Some additional nouns with variable plural, which are not listed in HAESERYN et al. (1997:165-184), with no intention of completeness:

aangifte 'information', aarde 'chemical oxide', antilope 'antelope', babylance 'baby ambulance', bende 'gang', complice 'accomplice', diagnose 'diagnosis', diepte 'depth', droogte 'dryness', einde 'end', elektrode 'electrode', extase 'extasy', fase 'phase', giraffe 'giraffe', globe 'globe', guave 'guava', hoeve 'farm', keuze 'choice', kribbe 'crib', lade 'drawer', made 'maggot', methode 'methods', microbe 'microbe', mythe 'myth', novelle 'novella', oekaze 'order', pauze 'break', periode 'period', piramide 'pyramid', route 'route', schade 'damage', schede 'sheath', snede 'cut', steppe 'steppe', sterkte 'strength', stobbe 'stump', strofe 'verse', synagogue 'synagogue', toelage 'extra pay', waarde 'worth', weduwe 'widow', weide 'pasture', winde 'bindweed', zijde 'side' etc.

Nouns which always take $n$-plural listed in HAESERYN et al. (1997:165-184)

Deadjectival person names: blinde 'blind person', overledene 'dead person', Groene 'person belonging to the Green party'

Others: gave 'gift', premisse 'premiss', seconde 'second'

Nouns which always take $s$-plural listed in HAESERYN et al. (1997:165-184)

dame 'lady', file 'traffic jam', visite 'visit' 


\section{References}

ANDERson, STEPHEN R. (1992): A-morphous morphology. Cambridge: Cambridge University Press (Cambridge Studies in Linguistics 62).

ARONOFF, MARK (1976): Word formation in generative grammar. Cambridge: MIT Press (Linguistic Inquiry Monographs 1$)$.

BOOIJ, GEERT E. (2002): The morphology of Dutch. Oxford/New York: Oxford University Press.

BooiJ, Geert E. \& van SAnten, Ariane (1998): Morfologie. De woordstructuur van het Nederlands. Amsterdam: Amsterdam University Press.

Braune, Wilhelm \& ReIfFENSTEIn, INGO ( $\left.{ }^{15} 2004\right)$ : Althochdeutsche Grammatik I. Laut- und Formenlehre. 15. Auflage. Tübingen: Niemeyer (Sammlung kurzer germanischer Dialekte A 5/1).

ByBEe, JoAn L. (1985): Morphology. A study of the relation between meaning of form. Amsterdam: John Benjamins.

Bybee, JoAn L. (1988): Morphology as lexical organization, in: HAMmond, Michael \& NoOnAN, Michael (eds.): Theoretical morphology. Approaches in modern linguistics. San Diego: Academic Press, 119-141.

DAMmel, ANTJE \& KÜRSCHNER, Sebastian (2008): Complexity in nominal plural allomorphy - A contrastive survey of ten Germanic languages, in: KARLSSON, Fred, MieSTAMO, MATTi \& SiNNEMÄKI, KAIUS (eds.): Language complexity: Typology, contact, change. Amsterdam: John Benjamins (Studies in Language Companion Series 94), 243-262.

DE RoOIJ, J. (1974): Dubbel meervoud I \& II, in: Taal en tongval 26, 46-69 \& 153-178.

DE SChutter, Georges (2001): Nasaal of schwa of allebei. De realisaties van het nasale meervoudssuffix bij substantieven in de Nederlandse dialecten, in: Taal en tongval 14, 113-141.

Donaldson, Bruce C. (1983): Dutch. A linguistic history of Holland and Belgium. Leiden: Martinus Nijhoff.

EMBICK, DAVID (2007): Blocking effects and analytic/synthetic alternations, in: Natural Language and Linguistic Theory 25, 1-37.

FEHRINGER, CAROL (2004): How stable are morphological doublets? A case study of $/ \mathrm{\partial} / \sim \emptyset$ variants in Dutch and German, in: Journal of Germanic linguistics 16/4, 285-329.

GoOSSENS, JAN (2000) [1975]: Konstituierendes in der Herausbildung der niederländischen Sprache, in: Goossens, JAN: Ausgewählte Schriften zur niederländischen und deutschen Sprach- und Literaturwissenschaft. Münster etc.: Waxmann (Niederlande-Studien 22), 213-228.

Haeseryn, W., Romijn, K., Geerts, G., De Rooij, J. \& VAn Den ToOrn, M. C. ( $\left.{ }^{2} 1997\right):$ Algemene Nederlandse Spraakkunst. Tweede geheel herziene druk. Groningen: Martinus Nijhoff.

HASPELMATH, MARTIN (2002): Understanding morphology. London: Arnold.

KIPARSKY, PAUL (2005): Blocking and periphrasis in inflectional paradigms, in: Yearbook of morphology 2004, 113-135.

KÖPCKE, Klaus-Michael (1993): Schemata in der Pluralbildung im Deutschen. Versuch einer kognitiven Morphologie. Tübingen: Narr (Studien zur deutschen Grammatik 47).

KROCH, ANTHONY (1994): Morphosyntactic variation. In: Katharine Beals et al. (eds.): Papers from the $30^{\text {th }}$ regional meeting of the Chicago Linguistics Society: Parasession on variation and linguistic theory. Chicago: Chicago Linguistics Society, 180-201.

KÜRSCHNER, SEBASTIAN (2006): De Nederlandse meervoudsallomorfie tussen Duitse complexiteit en Engelse eenvoud, in: HÜNInG, Matthias, Vogl, UlRike, VAN DER WOUdEN, TON \& Verhagen, ARIE (eds.): Nederlands tussen Duits en Engels. Handelingen van de workshop op 30 september en 1 oktober 2005 aan de Freie Universität Berlin. Leiden: SNL (SNL Reeks 15), 103-122.

KÜRSCHNER, SEBASTIAN (2008): Deklinationsklassen-Wandel. Eine diachron-kontrastive Studie zur Entwicklung der Pluralallomorphie im Deutschen, Niederländischen, Schwedischen und Dänischen. Berlin/New York: de Gruyter (Studia Linguistica Germanica 92).

MARYNISSEN, ANN (1996): De flexie van het substantief in het 13de-eeuwse ambtelijke Middelnederlands. Een taalgeografische studie. Leuven: Peeters.

NeEF, MARTIN (1996): Wortdesign. Eine deklarative Analyse der deutschen Verbflexion. Tübingen: Stauffenburg (Studien zur deutschen Grammatik 52).

NeEF, MARTin (1998): The reduced syllable plural in German, in: FABRI, RAy, OrTMAnN, Albert \& PARODI, TERESA (eds.): Models of inflection. Tübingen: Niemeyer (Linguistische Arbeiten 388). 
Paul, Hermann, Schröbler, Ingeborg, Wiehl, Peter \& Grosse, Siegfried ( $\left.{ }^{24} 1998\right)$ : Mittelhoch deutsche Grammatik. Tübingen: Niemeyer (Sammlung kurzer Grammatiken germanischer Dialekte A2).

PhILIPPA, MARLIES (1981): De meervoudsvorming op -s in het Nederlands vóór 1300, in: Tijdschrift voor Nederlandse taal- en letterkunde 97, 81-103.

PhiliPPA, MARLIES (1982): Problematiek rond het s-meervoud; een diachroon overzicht, in: De Nieuwe Taalgids 75, 407-417.

Ponelis, Fritz (1993): The development of Afrikaans. Frankfurt etc.: Peter Lang (Duisburg Papers on Research in Language and Culture 18).

Poser, William J. (1992): Blocking of phrasal constructions by lexical items, in: SAG, Ivan \& SzABOLSCI, ANNA (eds.): Lexical matters. Stanford: Center for the Study of Language and Information, 111-130.

RAIDT, EDITH H. (1983): Einführung in Geschichte und Struktur des Afrikaans. Darmstadt: Wissenschaftliche Buchgesellschaft.

Royen, P. Gerlach (1947): Buigingsverschijnselen in het Nederlands. Deel 1. Amsterdam: NoordHollandsche Uitgevers Maatschappij.

VAN DER Hulst, HARRY \& KoOIJ, JAN G. (1998): Prosodic choices and the Dutch nominal plural, in: Kehrein, Wolfgang \& Wiese, Richard (eds.): Phonology and morphology of the Germanic languages. Tübingen: Niemeyer (Linguistische Arbeiten 386), 187-197.

VAN HAERINGEN, COENRAAD BERNADUS (1949) [1947]: De meervoudsvorming in het Nederlands, in: VAn HAeringen, CoenraAd Bernadus: Neerlandica. Verspreide opstellen. 's-Gravenhage: Daamen's, 186-209.

van HAeringen, CoenraAd Bernadus (1956): Nederlands tussen Duits en Engels. Den Haag.

VAN LOEY, ADOLPHE ( $\left.{ }^{6} 1960\right):$ Schönfeld's historische grammatica van het Nederlands. Klankleer, vormleer, woordvorming. 6. Auflage. Zutphen: Thieme \& Cie.

VAN MARLE, JAAP (1987): Een mythe over het s-meervoud, in: Forum der letteren 28/4, 103-108.

Wegera, Klaus-Peter (1987): Flexion der Substantive, in Moser, Hugo, Stopp, Hugo \& Besch, WERNER (eds.): Grammatik des Frühneuhochdeutschen. Beiträge zur Laut- und Formenlehre vol. 3. Heidelberg: Winter.

Sebastian Kürschner

University of Groningen

Scandinavian Department

Postbus 716

9700 AS Groningen

The Netherlands

s.kurschner@rug.nl 